\title{
Standardization of blood meal production process at a rendering plant using design of experiments
}

\section{Padronização do processo de produção de farinha de sangue em uma usina de processamento por meio do planejamento de experimentos}

\author{
Juan Carlos Morales Piñero ${ }^{\text {*; }}$ John Alexander Clavijo2; \\ Edison Mauricio Rodríguez Ortiz ${ }^{2}$
}

\section{Highlights}

Factorial design is a tool that allows a clear path towards optimization.

It is necessary to ensure that the measurement system is under control.

Metering screw of the drying chamber is the factor that most influences the process.

\begin{abstract}
This research focuses on the standardization of the blood meal production process at a Colombian rendering plant through a design of experiments. Initially, 108 samples of blood meal were taken where only $23 \%$ achieved the moisture target (7.5\% to $8.5 \%$ ). Therefore, an analysis of the measurement system was performed using a repeatability and reproducibility (R\&R) study. Results showed that $39.96 \%$ of the observed variability was caused by the measurement system that was out of control. So, it was necessary to improve the method of sampling reducing the participation of the measurement system in the variability of the process to only $3.79 \%$. Later, several experiments were accomplished with a $2 \mathrm{k}$ factorial design. Each experiment consisted of a response variable (blood meal moisture), two controllable factors (drying chamber temperature and percentage of rotation of the metering screw), and an uncontrollable factor (initial blood meal moisture). Finally, experiments were carried out and validated observing that, with a drying chamber temperature of $160^{\circ} \mathrm{C}$ and a percentage of screw rotation of $29 \%$, more than $97 \%$ of the blood meal was according to the moisture target. In conclusion, is confirmed that the design of experiments is a tool that allows a clear path towards optimization and standardization of processes.
\end{abstract}

Key words: Standardization. Blood meal. Poultry rendering. Moisture. Design of experiments.

1 Researcher, Dr., Entrepreneurship and Management, Innovation Department, Sergio Arboleda University, SAU, Bogotá, Colombia. E-mail: juan.morales@usa.edu.co

2 Students, Master in Production and Operation, Sergio Arboleda University, SAU, Bogotá, Colombia. E-mail:jaclavijo13@ gmail.com; mauricio1k@hotmail.com

* Author for correspondence

Received: Nov. 11, 2020 - Approved: Feb. 24, 2021 


\section{Resumo}

Esta pesquisa se concentra na padronização do processo de produção de farinha de sangue de uma usina de beneficiamento colombiana por meio de um planejamento de experimentos. Em primeiro lugar, foi realizado um estudo de 108 amostras de farinha de sangue onde apenas $23 \%$ atingiram a meta de umidade $(7.5 \%$ a 8.5\%). Portanto, uma análise do sistema de medição foi realizada usando um estudo de repetibilidade e reprodutibilidade (R\&R). Os resultados mostraram que $39.96 \%$ da variabilidade observada foi causada pelo sistema. Assim, foi necessário aprimorar o método de amostragem, reduzindo a participação do sistema na variabilidade para apenas 3.79\%. Posteriormente, vários experimentos foram realizados com um planejamento fatorial $2 \mathrm{k}$. Cada experimento consistiu em uma variável de resposta (umidade da farinha de sangue), dois fatores controláveis (temperatura da câmara de secagem e porcentagem de rotação da rosca dosadora) e um fator incontrolável (umidade inicial da farinha de sangue). Finalmente, experimentos foram realizados e validados observando que, com uma temperatura da câmara de secagem de $160^{\circ} \mathrm{C}$ e um percentual de rotação da rosca de $29 \%$, mais de $97 \%$ da farinha de sangue estava de acordo com a umidade desejada. Em conclusão, confirma-se que o planejamento de experimentos é uma ferramenta que permite um caminho claro para a otimização e padronização de processos.

Palavras-chave: Padronização. Farinha de sangue. Processamento de aves. Umidade. Planejamento de experimentos.

\section{Introduction}

By-products of animal origin require specialized management because of the high environmental impact derived from the decomposition of organic materials. The process produces unpleasant smells, leachates that contaminate water sources, and the risk of proliferation of diseases caused by vectors such as rats or mosquitoes. The environmental and economically most efficient alternative for the use of by-products in the industry is the rendering plant. Rendering plants have changed, what until recently was a great problem for poultry producers, in an increasingly important industry in the agroindustry sector. The poultry rendering is the process that transforms the waste from the slaughterhouses into flours with a high nutritional value, which is used as raw material for the elaboration of animal food, especially for pets because of its high nutritional value (Barbut, 2015; Mahmood, Mirza, Nawaz, \& Shahid, 2018).

One of the critical systems in the operation of rendering plants is the production of flour from the processing of blood, given by its rapid decomposition. The transformation process removes the solid component from the blood and reduces the initial moisture by $88 \%$ to $8 \%$. The main stages that include this process are coagulation, decanting, and drying. During coagulation, the flash vapor is added, which in contact with the blood causes it solidifies. The action of adding steam $(150 \mathrm{~kg}$ per ton of blood) raises the blood moisture up to $89.6 \%$. The centrifuge decanter is immediately after the coagulator, which separates the solids from the liquid component and reduces the moisture to $68 \%$. Finally, it must pass through the flash dryer that draws humidity out quickly by hot air taking it to values below to $10 \%$. 
The moisture parameter of the final product (blood meal) defines its acceptance as a useful by-product for the industry. The National Renderers Association [NRA] (2008) establishes a maximum specification for the humidity of the blood meal by $10 \%$. Although there is no minimum parameter on this value, it is known that the over-drying of the blood meal involves the loss of the product.

In this sense, a preliminary study was carried out in a Colombian rendering plant where a total of 108 samples were analyzed for 4 days. The finding showed that only $23 \%$ of the sample was according to the moisture target (a minimum of $7.5 \%$ and a maximum $8.5 \%)$. That implied a loss of efficiency due to over-processing and loss of product due to over-drying (See results in Figure 1).

After analyzing the data, it was determined that the process was not standardized, which prevented the final product had stable characteristics. To control the final moisture of the blood meal the operator takes samples every 10 bags and examines the moisture balance. Based on the results, the operator adjusts one, two, or all three operating parameters according to experience. Since there was no formal procedure for sampling and measurement, a nested repeatability and reproducibility (R\&R) study was designed for the two operators (part) in order to quantify the variability of the measurement system following the methodology proposed by previous studies (Al-Refaie \& Bata, 2010; Johnson \& Deaner, 2014). A total of 10 samples were analyzed with two measurements per part, for a total of 40 runs. Results showed strong flaws in the measurement method, making the system not repeatable, contributing $39.96 \%$ of the variation with respect to tolerance (See Figure 2). If the variation of the measurement system is under $10 \%$, then it is acceptable, if not, it is out of control (Barbato, Vicario, \& Levi, 2008).

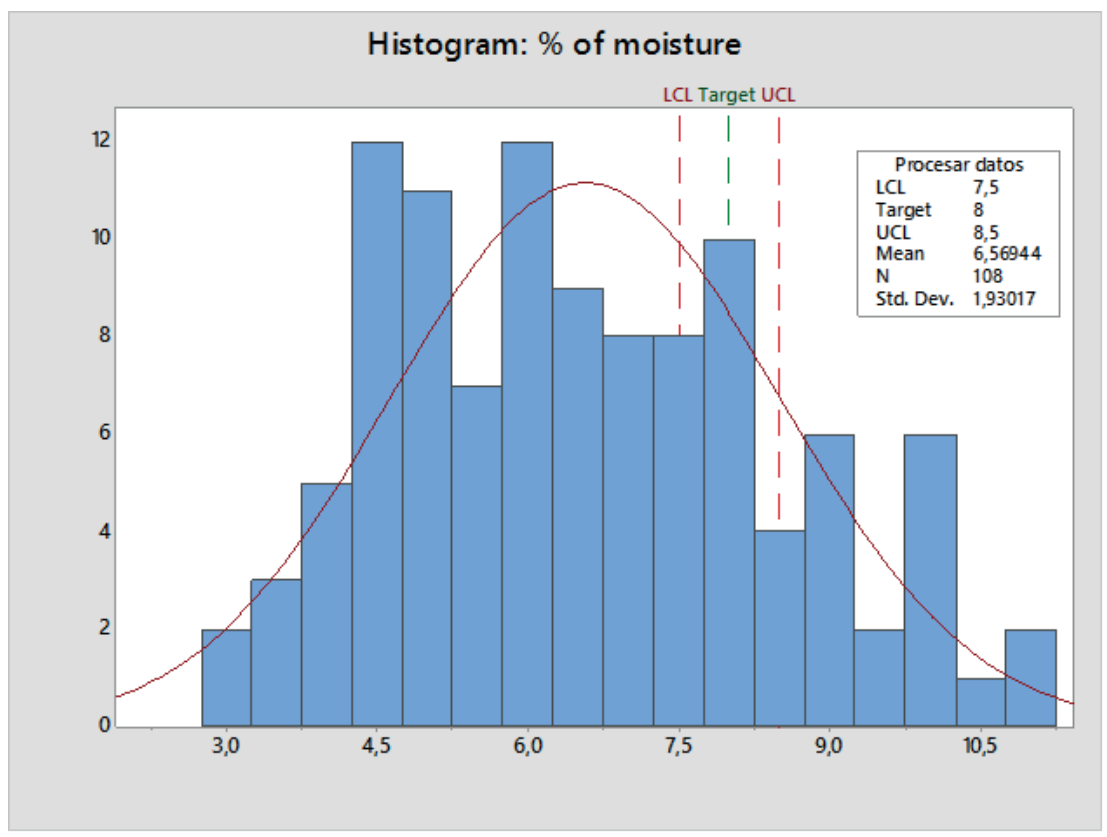

Figure 1. Initial Frequency Chart. 


\section{Gage R\&R (Nested) Report for Responses

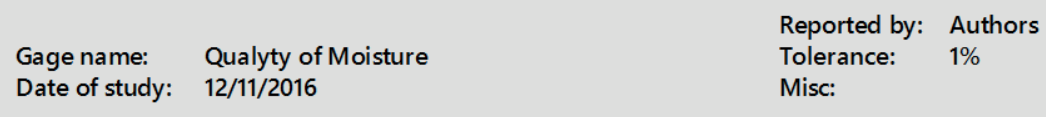

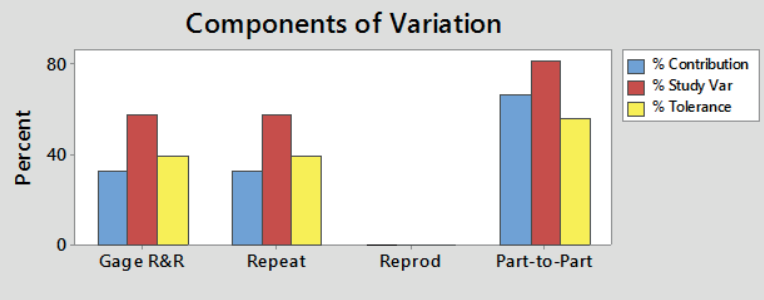
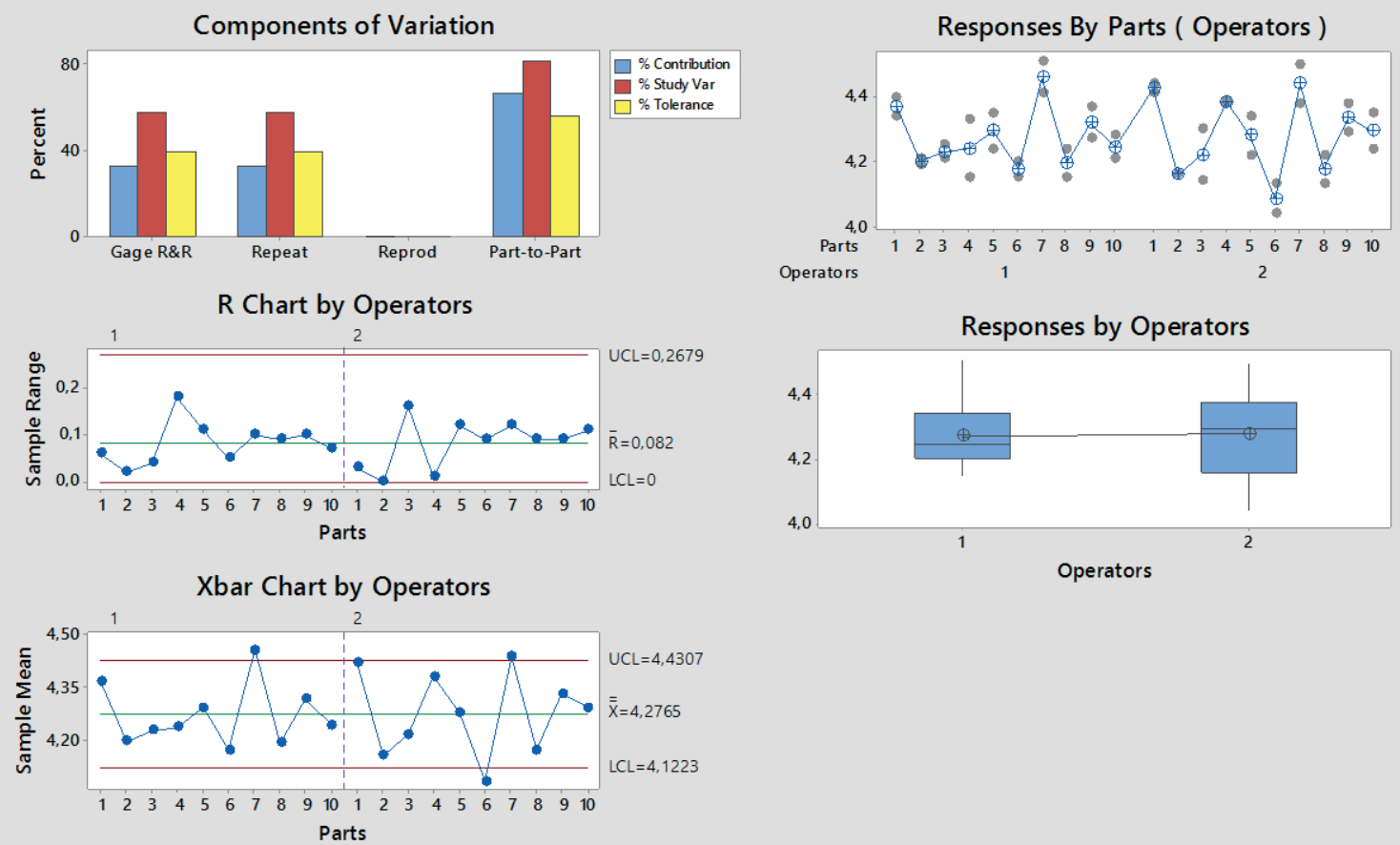

Figure 2. Initial R\&R Study.

Given the results, this work focuses on the standardization of the parameters of the blood meal production process to obtain a robust operation process in order to get the quality and productivity requirements. The study was conducted through the design of experiments with a $2 \mathrm{k}$ factorial design, which has been used in differentstudies (Lebouachera et al., 2019; Piñeres-Espitia, Cama-Pinto, De la Rosa, Estevez, \& Cama-Pinto, 2017; Ribeiro et al., 2019; Romero-Conrado, Suárez-Agudelo, Macías-Jiménez, Gómez-Charris, \& LozanoAyarza, 2017).
Materials and Method

A production process is a system of actions that are dynamically interrelated and oriented towards the transformation of certain elements. In this way, the input elements (known as factors) become output elements (products), after a process in which their value is increased. In terms of the design of experiments, a process includes inputs (factors), which can be controllable (Xs) and non-controllable (Zs), and outputs (Ys) known as the response. 
Thus, an experimental design is a research technique that allows to effectively and efficiently exploring the causal relationship between multiple variables $(X)$ on the output variable $(Y)$ of a process. In a design of experiments, a series of tests are performed in which step-type changes (from a low to a high level) are introduced into the input variables (Xs) of a process. This allows observing and identifying the causes of the changes in the output variable (Y). Given that the objective of this study, a 2-level design called $2 \mathrm{k}$ full factorial design was used, following the previous works (Medina D. \& Lopez R., 2011).

Minitab 17 statistical software was used for data analysis, to identify probabilistic patterns that describe the behavior of the systems. To conduct the experiment, the general guidelines proposal by Montgomery was applied (Montgomery, 2012): problem

Recognition and statement of the

Choice of factors, levels, and ranges

Selection of the response variables

Choice of experimental design

Performing the experiment

Statistical analysis of the data

Test and validation of the model

Conclusions and recommendations.
All the experimentation concepts were incorporated using the guideline presented by Grima, Marco and Tort-Martorell, (2011). In the following section, each stage was applied.

\section{Results and Discussion}

Prior to the development of the experiment, it was necessary to adjust the measurement system to guarantee the quality of the analyzed data. In conjunction with the Quality Department of the firm and with the support of the equipment supplier (moisture balance), a training plan was developed for those operators responsible for sampling and measurement. In addition, it was necessary to provide suitable premises to install the equipment and to ensure the system operation. A validation routine was established through a new R\&R study with the same characteristics. The results are shown in Figure 3. 


\section{Gage R\&R (Nested) Report for Response

$\begin{array}{lll} & & \text { Reported by: Authors } \\ \text { Gage name: } & \text { Quality of Moisture } & \text { Tolerance: } \\ \text { Date of study: } & 20 / 12 / 2016 & \end{array}$
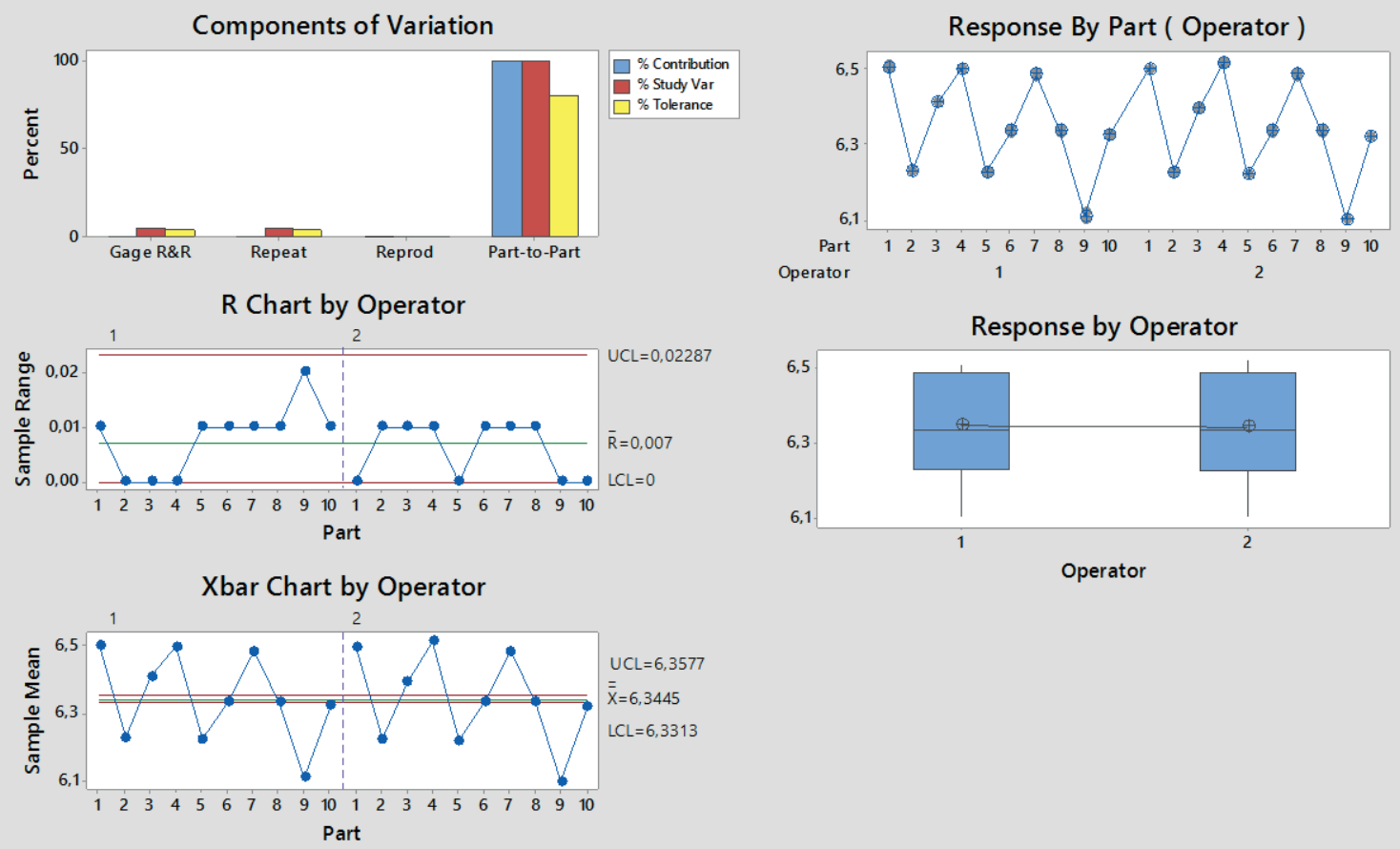

Figure 3. New R\&R Study.

The results of the latest $\mathrm{R}$ \& $\mathrm{R}$ study for the measurement system, shows a substantial improvement, reducing the influence of the measurement system in the variability observed from $39.96 \%$ to only $3.79 \%$. Once the measurement system was adjusted, the design of the experiment was carried out in order to normalize the process.

\section{Recognition and statement of the problem}

The flash drying system lacked standardization and there was no clarity in the influence of each factor on the final moisture of the blood meal. In addition, the operator constantly modified the parameterization of the process factors. The operating ranges were quite broad, and the measuring system was not calibrated.

All this contributes to the system comes out of control by the high dispersion of the data. For that reason, the average moisture of the blood meal was outside the specified limits. Consequently, only $23 \%$ of the final product was according to the moisture range. 
Choice of factors, levels, and ranges

The flash drying system consists of a vertical drying chamber where the wet blood meal is added by a metering screw. A hot air stream flows from the gas burner to the vertical drying chamber. Subsequently, a battery of cyclones is used to separate the blood meal from the air. Figure 4 shows the scheme for a flash drying system.

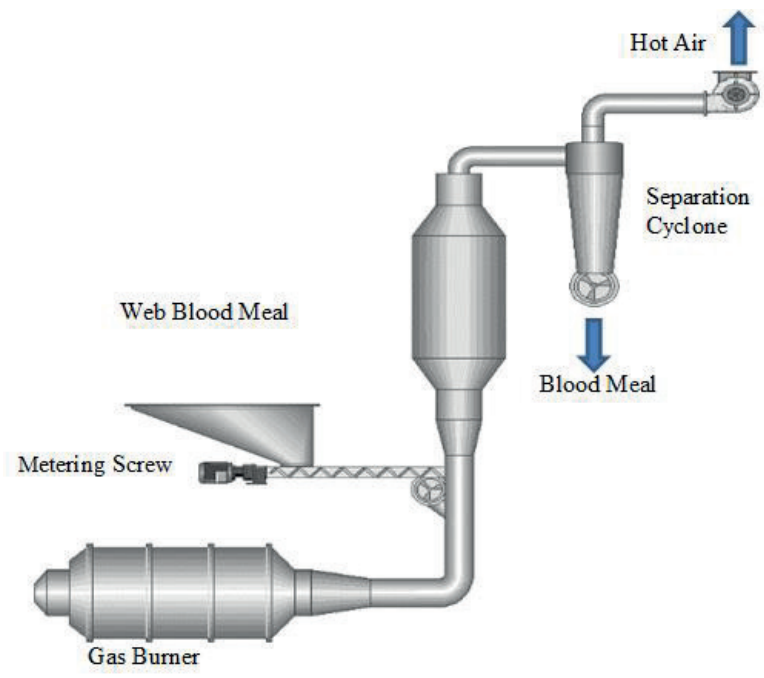

Figure 4. Flash drying system.

According to the characteristics of the flash drying system, the possible factors and their current ranges of operation to be incorporated in the experiment were defined and are showed in Table 1.

\section{Table 1}

\section{Parameters of the process}

\begin{tabular}{lccc}
\hline Factors & Minimum & Maximum & Ranges \\
\hline Airflow & $5800 \mathrm{~m}^{3} \mathrm{~h}^{-1}$ & $5800 \mathrm{~m}^{3} \mathrm{~h}^{-1}$ & $0 \mathrm{~m}^{3} \mathrm{~h}^{-1}$ \\
\hline Temperature of the gas burner & $300{ }^{\circ} \mathrm{C}$ & $360^{\circ} \mathrm{C}$ & $60^{\circ} \mathrm{C}$ \\
\hline Temperature of the chamber & $130{ }^{\circ} \mathrm{C}$ & $200{ }^{\circ} \mathrm{C}$ & $70{ }^{\circ} \mathrm{C}$ \\
\hline rotation of the metering screw & $25 \%$ & $45 \%$ & $20 \%$
\end{tabular}

Once the factors that intervene in the process were analyzed, the airflow rate was excluded from the experiment because it was not possible to change their value to different levels of operation. The temperature of the burner was also excluded because it will be continually changing as required by the drying chamber. In this way, only two factors remained: the percentage of rotation of the metering screw and the temperature range in the drying 
chamber. That is consistent with a previous study conducted in a rendering plant which determined that a combination of temperature and time were the parameters that significantly determine the ultimate quality of the products (Awonorin, Ayoade, Bamiro, \& Oyewole, 1995; Farmanesh, Mohtasebi, \& Omid, 2019).

The noise factor for this experiment is the incoming moisture of the blood meal. During the first hours, the blood from slaughter plants has little water contamination and its humidity after the settling phase is $64 \%$. However, it is normal that at the end of the process in the slaughterhouses, the blood has a high-water load, increasing humidity by up to five percentage points to $69 \%$. For a definition of possible levels of each factor, the data of five days of the process were analyzed and grouped in ranges agreed with the areas of engineering and production, as shows in Table 2.

\section{Selection of the response variables}

The objective of the experiment was to optimize the final moisture of the blood meal by minimizing its variability. That is, adjusting the final moisture to the target value for a dispersion that does not exceed the established limits.

\section{Table 2}

\section{Selected levels for the experiment}

\section{Factors}

Temperature of the chamber in ${ }^{\circ} \mathrm{C}$

$\%$ rotation of the screw

Initial moisture

\section{Low level}

$142-152$

$26-31$

$64 \%$

\section{High level}

$172-182$

$44-50$

$69 \%$

\section{Choice of experimental design}

Because it is a robust process design, the parameters must not only optimize the variable response to a target value but also minimize the dispersion of the same. For this reason, the experiment must include a variability analysis. Another element to consider is the noise factor that should be included in the study. According to these considerations, a 22 full factorial design with two replicates was chosen, for a total of eight runs. The model was as follow:

$$
y=\beta 0+\beta 1 A+\beta 2 B+\beta 3 A B+\varepsilon,
$$

where:

$\beta$ means regression coefficients, y final moisture, A temperature of the chamber (TempChamber), B rotation of the screw (Rot-Screw) and $\varepsilon$ means error term.

\section{Performing the experiment}

For the development of the experiment the first four runs were made at the start of the process when the moisture (input) is low, and the replica at the end when the moisture is high. The time used in each run was twenty-five minutes for a total of one hundred minutes per replica. The results are shown in Table 3. 
Table 3

Experimental treatment

\begin{tabular}{ccccccc} 
Runs & \multicolumn{2}{c}{ Factors to be controlled } & \multicolumn{2}{c}{$\begin{array}{c}\text { Noise factor } \\
\text { Initial moisture }\end{array}$} \\
& Temp-Chamber & Rot-Screw & $64 \%$ & $69 \%$ & Mean & Std. Dev. \\
\hline 1 & 147 & 29 & 8.62 & 9.67 & 9.15 & 0.74 \\
2 & 177 & 29 & 5.98 & 7.05 & 6.52 & 0.76 \\
3 & 147 & 47 & 11.7 & 12.88 & 12.29 & 0.83 \\
4 & 177 & 47 & 9.16 & 10.36 & 9.76 & 0.85
\end{tabular}

Statistical analysis of the data

Based on the results of the factorial analysis, a chart of the main effects and their interactions was determined as shown in Figure 5. It can be deduced that only the main effects are significant, but not their interaction.

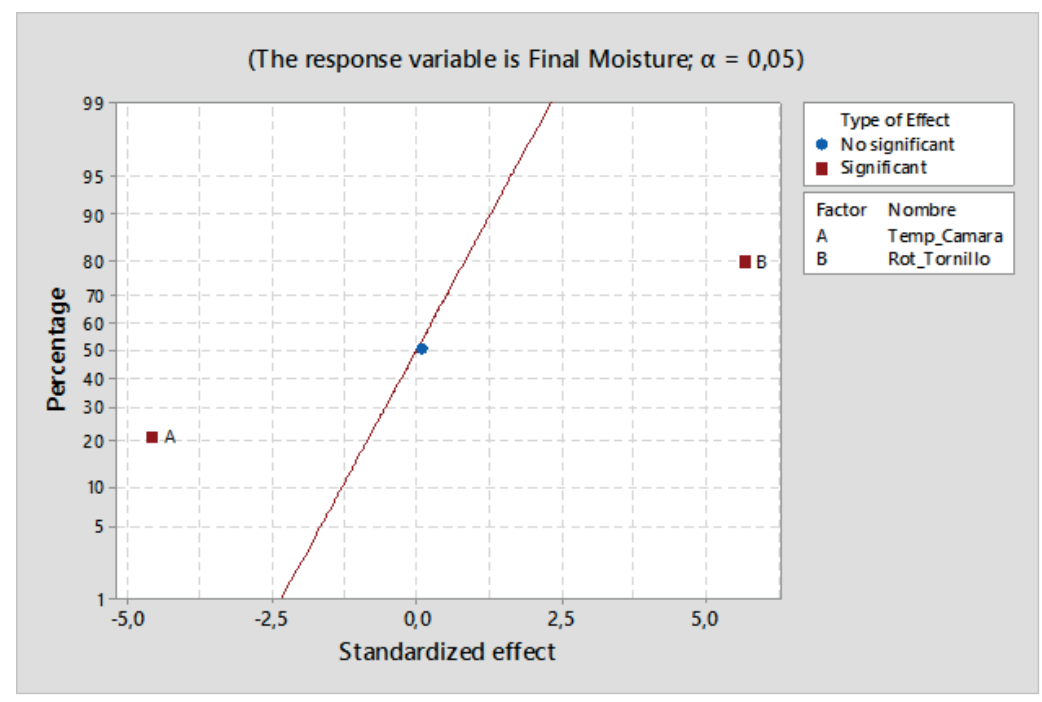

Figure 5. Chart of the standardized effects.

In these results, the model explains $93.00 \%$ of the variation of the final moisture. For these data, the $\mathrm{R}^{2}$ value indicates the model provides a good fit to the data. Details can be seen in Table 4. The model summary of non-coded coefficients is as follow:
Final Moisture $=17.8-0.0930$ Temp-Chamber + 0.148 Rot-Screw + 0.00019 Temp-Chamber

${ }^{*}$ Rot-Screw 
Table 4

Coded Coefficients

\begin{tabular}{lccccc}
\multicolumn{1}{c}{ Term } & Effect & Coef & SE Coef & T-Value & P-Value \\
Constant & & 9.427 & 0.282 & 33.46 & 0.000 \\
Temp_Chamber & -2.580 & -1.290 & 0.282 & -4.58 & 0.010 \\
Rot_Screw & 3.195 & 1.598 & 0.282 & 5.67 & 0.005 \\
Temp_Chamber * Rot_Screw & 0.050 & 0.025 & 0.282 & 0.09 & 0.934
\end{tabular}

To improve the model, factor analysis was carried out again, excluding the interaction of the main factors, since its effect is not significant $(p>0.05)$ in the response variable. In this new analysis, the $\mathrm{R}^{2}$ value continues showing a good fit: $92.98 \%$. Both, the model and the coefficients have $p<\alpha$ therefore are accepted. The new regression model has the following form:

Final Moisture $=16.61-0.0860$ TempChamber + 0.1775 Rot-Screw
Subsequently, a variability (S) analysis of the residuals was performed including all the terms. Results showed that there were no significant effects; however, the interaction was the least significant, and its degrees of freedom could influence the result. For that, a new analysis was performed without considering the interaction and the new model improved the fit; the main effects become significant (see Figure 6) and the regression model coefficients were accepted.

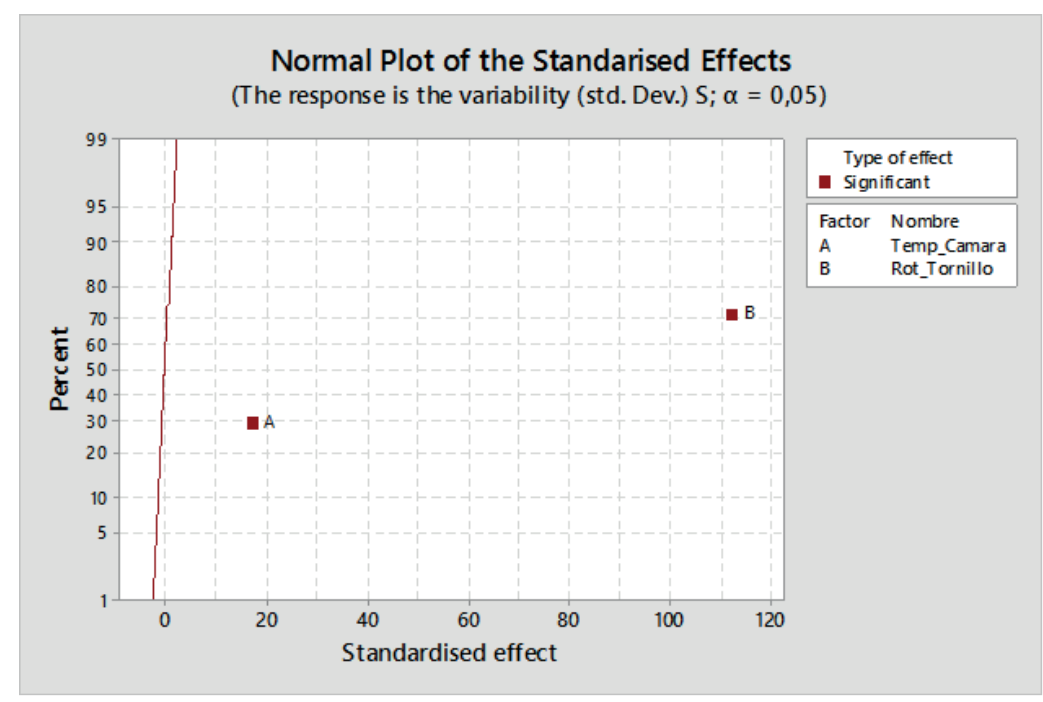

Figure 6. Variability (S) analysis of the residuals. 
The percentage of screw rotation is the effect that has the most impact on the final moisture of the blood meal and contributes most to the variability of the process. The regression model for variability (s) present a good fit ( $R^{2}$ 99.98\%) as shown:

$$
\begin{gathered}
\operatorname{Ln}(S)=-0.57107+0.000595 \text { Temp-Chamber } \\
+0.006427 \text { Rot-Screw }
\end{gathered}
$$

To explore the possible operation values for each factor, a contour plot was generated (Figure 7), showing the potential relationship between the final moisture of the flour Vs temperature of the drying chamber and the rotation percentage of the screw. The dark band shows all possible combinations of factors to obtain final moisture within the expected parameters $(7.5>M<8.5)$.

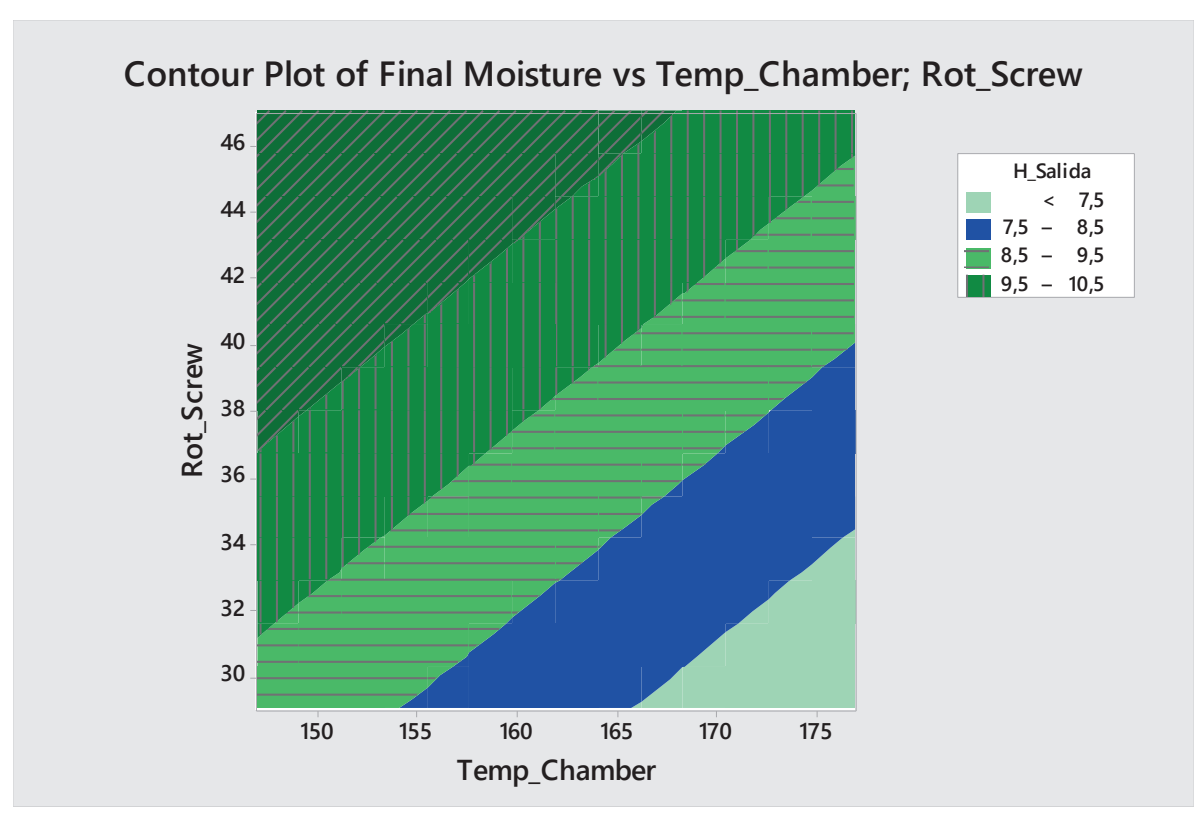

Figure 7. Contour Plot of Final Moisture vs Temp_Chamber; Rot_Screw.

To obtain the target moisture and minimizing the variability in the process, the Minitab response optimizer was used, combining the two models. The results of Figure 8 show that the increase in chamber temperature increases the variability but decreases the final moisture. Then, the optimal setting is in the middle of the range $\left(160^{\circ} \mathrm{C}\right)$. Results also show that increasing the rotation of the screw increases the final moisture. The optimum operating parameter obtained for this factor was at the minimum level in the experiment (29\%). 


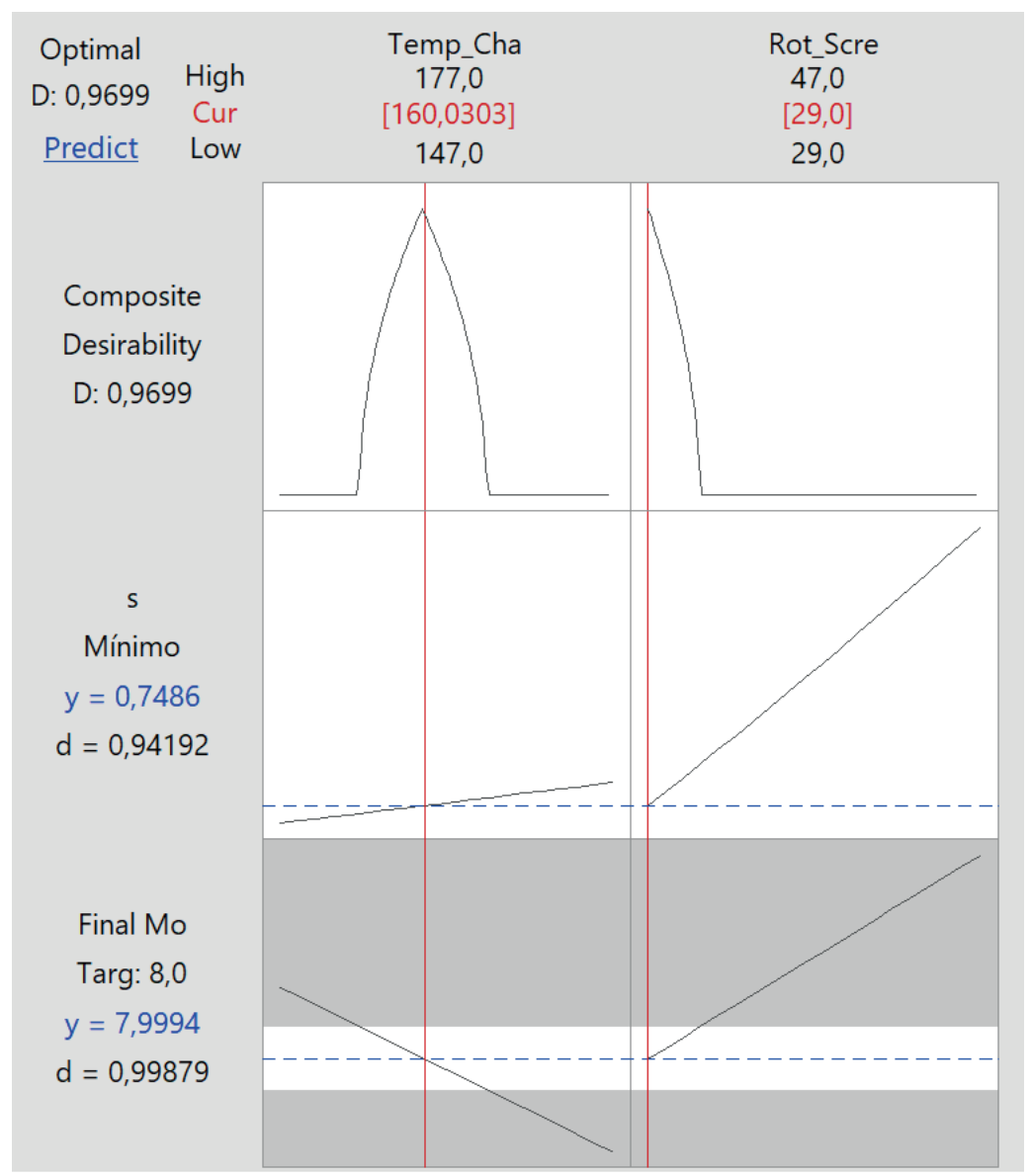

Figure 8. Optimization of parameters.

Test and validation of the model

In the next stage, the system was adjusted to the new parameters and 42 measurements of the moisture were carried out in order to test and validate the model. Figure 9 shows the frequency chart and the probability plot of the final moisture of the blood meal.
As can be seen, moisture exhibits normal behavior and the mean is nearly the target value. However, the data dispersion, although lower than initially observed, remains high relative to specification limits. The regression analysis shows a good fit $\left(\mathrm{R}^{2}\right.$ $90 \%)$, although two atypical observations were detected. 


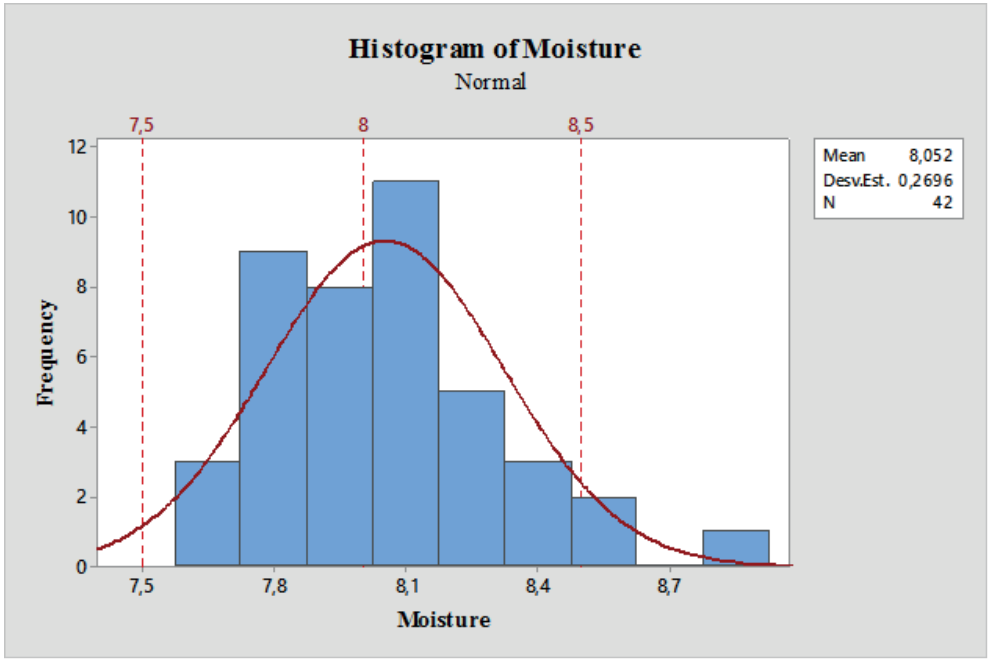

Figure 9. Final Frequency Chart.

Consequently, a new analysis was made excluding these two values and the $\mathrm{R}^{2}$ was adjusted to $95 \%$. As shown in Figure
10, the residues have a normal distribution appearance, have non-tendency, and are set within a range.

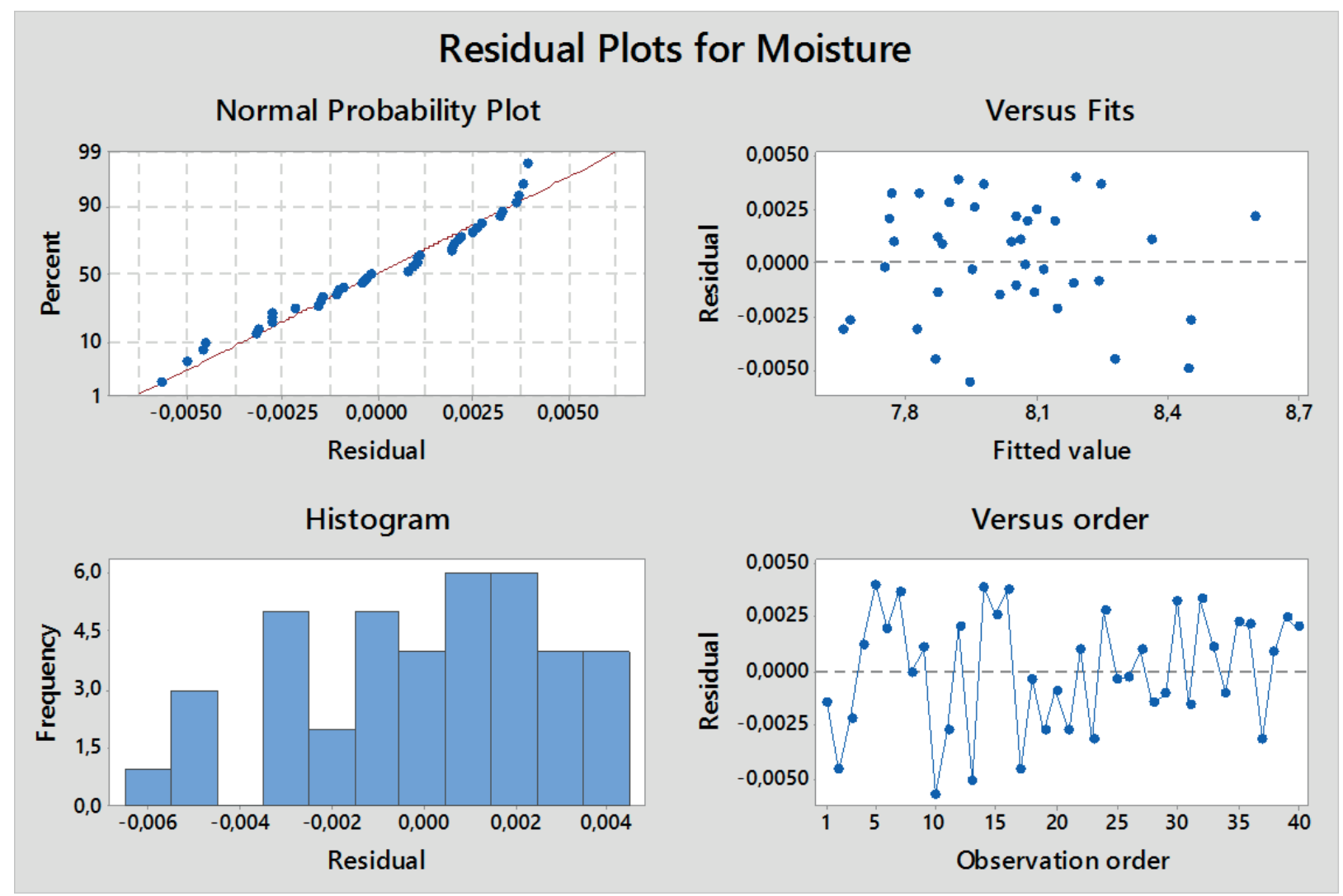

Figure 10. Residual Plot of the model. 
The final tested and validated regression model explains $95 \%$ of the behavior of the moisture of the blood meal in relation to the drying chamber temperature and screw rotation percentage.

\section{Final Moisture $=16.6118-0.085950$ Temp- \\ Chamber + 0.177205 Rot-Screw}

Finally, an analysis of capacity to the drying system was performed operating under the new parameterization. Results show that the process slightly deviates towards the upper limit, the dispersion, although it is much lower than initially observed, remains high in relation to the specification limits. In the long term, only $2.56 \%$ of the final product will be outside the specification.

\section{Conclusions}

Our study shows the importance of having R\&R studies to ensure that measurement systems are well-calibrated and standardized. In the same way, we demonstrate the robustness of the design of experiments through factorial design, as a tool that allows a clear path towards optimization, standardization, and assurance of processes. In the case of the blood meal process, we conclude that the percentage of rotation of the metering screw of the drying chamber is the factor that most influences the process.

\section{References}

Al-Refaie, A., \& Bata, N. (2010). Evaluating measurement and process capabilities by GR\&R with four quality measures. Measurement, 43(6), 842-851. doi: 10.1016/j.measurement.2010.02.016
Awonorin, S. O., Ayoade, J. A., Bamiro, F. O., \& Oyewole, L. O. (1995). Relationship of rendering process temperature and time to selected quality parameters of poultry by-product meal. LWT - Food Science and Technology, 28(1), 129-134. doi: 10.1016/ S0023-6438(95)80024-7

Barbato, G., Vicario, G., \& Levi, R. (2008). Measurement system analysis. In $\mathrm{S}$. Coleman, T. Greenfield, D. Stewardson, \& D. Montgomery (Eds.), Statistical practice in business and industry (pp. 239-305). West Sussex: John Wiley \& Sons.

Barbut, S. (2015). Waste treatment and by-products. In S. Barbut (Ed.), The science of poultry and meat processing (pp. 723-749). Guelph: University of Guelph. Retrieved from http://download. poultryand meatprocessing.com/v01/ SciPoultryAndMeatProcessing - Barbut 18 Byproducts and Waste - v01.pdf

Farmanesh, A., Mohtasebi, S. S., \& Omid, M. (2019). Optimization of rendering process of poultry by-products with batch cooker model monitored by electronic nose. Journal of Environmental Management, 235, 194-201. doi: 10.1016/j.jenvman. 2019.01.049

Grima, P., Marco, L., \& Tort-Martorell, X. (2011). Estadística con minitab: aplicaciones para el control y la mejora de la calidad. Madrid: Garceta.

Johnson, L., \& Deaner, M. (2014). Necessary measures expanded gage $R$ and $R$ to detect and control measurement system variation. Quality Progress, 47(7), 34-38.

Lebouachera, S. E. I., Chemini, R., Khodja, M., Grassl, B., Abdelfetah Ghriga, M., Tassalit, D., \& Drouiche, N. (2019). Experimental 
design methodology as a tool to optimize the adsorption of new surfactant on the Algerian rock reservoir: cEOR applications. The European Physical Journal Plus, 134(9), 1-15. doi: 10.1140/epjp/i201912821-9

Mahmood, T., Mirza, M. A., Nawaz, H., \& Shahid, M. (2018). Exogenous protease supplementation of poultry by-product meal-based diets for broilers: Effects on growth, carcass characteristics and nutrient digestibility. Journal of Animal Physiology and Animal Nutrition, 102(1), e233-e241. doi: 10.1111/jpn. 12734

Medina D., P., \& Lopez R., Á. (2011). Análisis crítico del diseño factorial $2 \mathrm{~K}$ sobre casos aplicados. Scientia Et Technica, XVII(47), 101-106. Retrieved from http://www. redalyc.org/articulo.oa?id=84921327018

Montgomery, D. C. (2012). Design and analysis of experiments. Danvers MA: John Wiley \& Sons, Inc.

National Renderers Association (2008). Pocket information manual: a buyer's guide to rendered products. Alexandria: National Renderers Association, Inc. Retrieved from http://assets.nationalrenderers.org/ pocket_information_manual.pdf
Piñeres-Espitia, G., Cama-Pinto, A., De la Rosa, D., Estevez, F., \& Cama-Pinto, D. (2017). Design of a low cost weather station for detecting environmental changes. Espacios, 38(59), 1-13.

Ribeiro, L. B., Bankuti, F. I., Silva, M. U. da, Ribeiro, P. M., Silva, J. M., Sato, J., Vasconcellos, R. S. (2019). Oxidative stability and nutritional quality of poultry by-product meal: an approach from the raw material to the finished product. Animal Feed Science and Technology, 255, 114226. doi: 10.1016/j. anifeedsci.2019.114226

Romero-Conrado, A. R., Suárez-Agudelo, E. A., Macías-Jiménez, M. A., GómezCharris, Y., \& Lozano-Ayarza, L. P. (2017). Diseño experimental para la obtención de compost apto para uso agrícola a partir de lodo papelero Kraft. Espacios, 38(28), 1-14. 
